\title{
BNWL-187
}

36

\section{PURIFICATION OF RARE EARTHS FROM HANFORD WASTES BY SOLVENT EXTRACTION}

RESEARCH and DEVELOPMENT REPORT

\section{A. BRAY and F. P. ROBERTS}

\author{
FEBRUARY, 1966
}

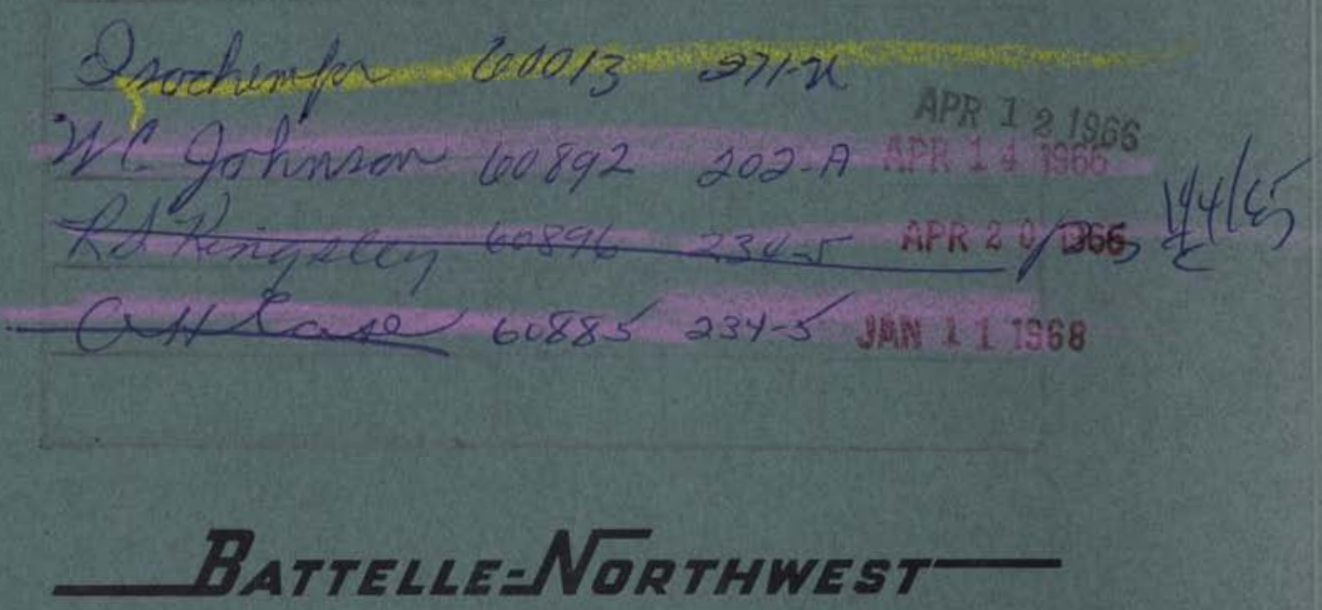

BATTELLE MEMORIAL INSTITUTE / PACIFIC NORTHWEST LABORATORY 


\section{LEGAL NOTICE}

This report was prepared as an account of Government sponsored work. Neither the United States, nor the Commission, nor any person acting on behalf of the Commission:

A. Makes any warranty or representation, expressed or implied, with respect to the accuracy, completeness, or usefulness of the information contained in this report, or that the use of any information, opparatus, method, or process disclosed in this report may not infringe privately owned rights; or

B. Assumes any liabilities with respect to the use of, or for damages resulting from the use of any information, apparatus, method, or process disclosed in this report.

As used in the above, "person acting on behalf of the Commission" includes any employee or contractor of the Commission, or employee of such contractor, to the extent that such employee or con. tractor of the Commission, or employee of such contractor prepores, disseminates, or provides access to, any information pursuant to his employment or contract with the Commission, or his employment with such contractor:

\section{PACIFIC NORTHWEST LABORATORY \\ RICHLAND, WASHINGTON \\ operated by \\ BATTEULE MEMORIAL INSTITUTE}

for the

UNITED STATES ATOMIC ENERGY COMMISSION UNDER CONTRACT AT(45-1)-1830 
BNWL- 187

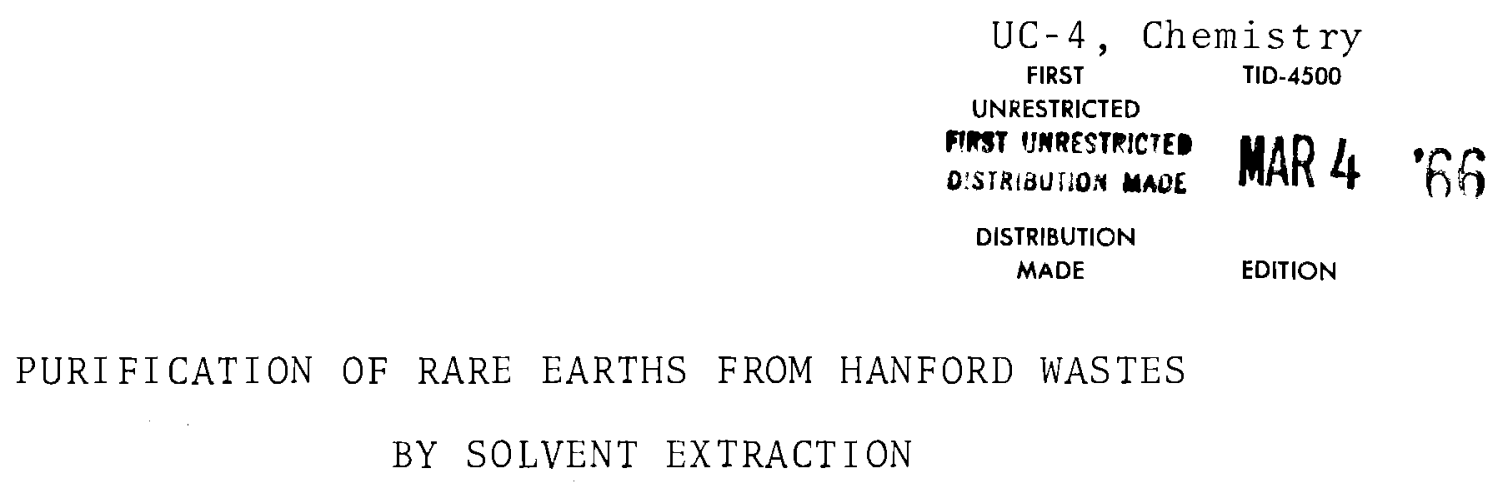

By

L. A. Bray and F. P. Roberts

Chemical Research Section

Chemistry Department

February, 1966

PACIFIC NORTHWEST LABORATORY

RI CHLAND, WASH INGTON 
Printed in USA. Price $\$ 2.00$. Available from the Clearinghouse for Federal Scientific and Technical Information, National Bureau of Standards, $U . S$. Department of Commerce, Springfield, Virginia 
TABLE OF CONIENTS

I. INIRODUCTION

Page

II. SUMMARY

III. RESUITS AND DISCUSSION

A. Co-extraction of Cerium and Rare Earths

1. Separation of Manganese by Solvent Extraction

2. Separation of Manganese by Sulfate Preclpltation

B. Partition of Cerlum from Trivalent Rare Earths

1. Effect of Radiation on the Solvent

2. Effect of Pre-oxidation of Cerium

3. Solubility of Pergulfate

4. Str1pping the $\mathrm{Ce}($ IV) Loaded Solvent

C. Re-extraction of Trivalent Rare Earths

1. Trivalent Rare Earth Lовве During the Sulfate-Silver Removal Step

2. Concentration and Denitration of the Rare Earth Product

IV. FUTURE RARE EARTH PROCESSIIG

V. ACKMOWLEDGEMENIS

VI. REFERENCES 


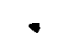

$\bullet$ 
I. INTRODUTTION

A prcess was recently developed $(I)$ for separating cerium from the trivalent rare earths. This process consists of three steps:

A) coextraction of cerium and trivalent rare earths from an aqueous solution complexed with $\mathrm{N}$-hydroxyethylethylenediaminetriacetic acid (HEDPA) or other suitable complexing agent (to prevent extraction of ions such as lead) at a $\mathrm{pH}$ above 1.5 .

B) partition of cerium from the trivalent rare earths by stripping the latter into $2 \mathrm{M} \mathrm{HNO}_{3}$ containing persulfate and silver ions. The cerium is oxidized to cerium(IV) and remains in the organic phase.

C) re-extraction of the trivalent rare earths at a $\mathrm{pH}$ greater than 1.5 to remove the sulfate which is formed on decomposition of persulfate, as well as silver.

Several problems have become evident from actual experience using this process on a plant scale.

The first problem was the need to separate manganese from the rare earths in the co-extraction step. Manganese, which is present in Purex wastes from its use in the solvent clean-up, interferes seriously in the persulfate oxidation of cerium. The oxalate precipitation method used to recover rare earths from the waste did not provide for manganese removal. As a result, the crude cerium-rare earth feed contained large quantities of manganese which had to be removed prior to the persulfate step.

The second problem is that with repeated use of the solvent the partition step becomes marginal because radiolysis of the solvent generates reducing impurities which consume the persulfate and prevent oxidation of cerium to the quadrivalent state.

The third problem is the loss of trivalent rare earths during the sulfate-silver removal step. This has been found to be caused by 
precipltation of rare earth double sulfates when the $\mathrm{pH}$ is adjusted for the re-extraction step.

The results of studies designed to alleviate these problems are presented in this report.

II. SUMMARY

The co-extraction of cerium and rare earths into $0.4 \mathrm{M} d 1$ (2-ethylhexyl) phosphoric acid (D2EHPA) - 0.2M tri-n-butyl phosphate (TBP) is complicated if large quantities of manganese are present. (>0.25 g Mn/l will interfere with the subsequent oxidation of cerium with persulfate-silver.) Although this situation may not occur in future rare earth processing, a separation scheme had to be found for processing a large batch of current feed material. Both laboratory and hot-cell experiments showed that a good separation of manganese and the rare earths is possible by controlled pH solvent extraction. Because $\mathrm{pH}$ control is very difficult in the plant, wreliable results and high product losses occurred in the full-scale tests; the D2EHPA solvent extraction scheme for manganese removal proved impractical. An alternate scheme, based on sulfate preclpitation was developed. This process, although complicated by the lack of a centrifuge in the plant does not require $\mathrm{pH}$ control. The steps involved are:

a) Rare earth precipitation by the eddition of $\mathrm{IaBSO}_{4}$ to $2.5 \mathrm{M} \mathrm{SO}_{4}=$, 15 minutes digestion at $80 \mathrm{C}$, and one hour for precipitate settling.

b) Decantation (drainage of the tank through a dip leg followed by a $1 \mathrm{M} \mathrm{Na}_{2} \mathrm{SO}_{4}$ wash).

c) Metathesis with $3.5 \mathrm{M}$ NaOH (35c).

d) Dissolution with $\mathrm{ENO}_{3}$ - HEDTA.

e) Extraction of the rare earths into D2EHPA. 
Preliminary Semiworks results indicate 85 - 95 per cent rare earth recovery through step e; anda an adequate manganese decontamination factor of $50-100$

The separaition of cerlum from trivalent rare earths with D2EHPA, is 1mproved by the substitution of a straight chain hydrocarbon diluent for the branched chain dilueat used previously. The effect of radiolysis is markedly reduced and high cenium disirribution ratios are maintained.

The solubilities of both $\mathrm{K}_{2} \mathrm{~S}_{2} \mathrm{O}_{8}$ and $\mathrm{Na}_{2} \mathrm{~S}_{2} \mathrm{O}_{8}$ were measured as a function of $\mathrm{HNO}_{3}$ concentratios at $25 \mathrm{C}$. The sodium salt was found to be much more soluble than $K_{2} \mathrm{~S}_{2} \mathrm{O}_{3}$ In all cases. Solubility of $\mathrm{K}_{2} \mathrm{~S}_{2} \mathrm{O}_{8}$ in $0,1,2$ and $4 \underline{\mathrm{M}}$ $\mathrm{HNO}_{3}$ was $0.22,0.26,0.28$ and $0.37 \underline{M}$; solubillty of $\mathrm{Na}_{2} \mathrm{~S}_{2} \mathrm{O}_{8}$ was $2.4 \mathrm{M}$ in $\mathrm{H}_{2} \mathrm{O}$ and 1.TM in $2 \mathrm{M} \mathrm{FNO}_{3}$. Performance of the two chemlcals was 1dentical. Use of the more soluble and less expensive $\mathrm{Na}_{2} \mathrm{~S}_{2} \mathrm{O}_{8}$ simplifies plant solution make-up and permits substantial savings.

Cerium distribution ratios of Ereater than 100 were obtained in 10 minutes when the aqueous phase was preoxidized 45 minutes before contact with the organfc extrastant. The aqueous phase was adjusted to contain $0.1 \mathrm{M} \mathrm{K}_{2} \mathrm{~S}_{2} \mathrm{O}_{3}, 0.02 \mathrm{M}$ silver, and $2 \mathrm{MHNO}_{3}$. Lower concentrations of either silver or persulfate resuited in marginal distribution ratios.

Sodium nitxite $\left(0.005\right.$ to $0.05 \underline{\mathrm{M}}$ in $\left.2 \mathrm{M}^{\mathrm{M}} \mathrm{HNO}_{3}\right)$ was shown to be effective for stripping cerium(IV) from D2EHPA. Ninety-five per cent of the cerium in the organic solvent can be sirlpped into $2 \mathrm{M} \mathrm{HNO}_{3}$ containing $0.05 \mathrm{M} \mathrm{NaNO}$ with a 5 minute contact. With $0.005 \mathrm{M} \mathrm{NaNO}_{2}$ a 25 minute contact was needed. With no addea $\mathrm{NaNO}_{2}$ a 220 minute contact was needed. Addition of HEITA to rare earth solutions containing sulfate prevents precipltailon of rane earth couble sulfates at pH vaiues greater than about 
2.8 while still permitting extraction and hence separation from sulfate. Distribution ratios for silver under these conditions are generally quite low.

A sugar denitration and concentration procedure was developed and guccessfully demonstrated to obtain a feed for further ion exchange processing.

III. RESUTIS AND DISCUSSION

\section{A. Co-extraction of Cerium and Rare Esrths}

The intilal step in the process for separating cerlum from rare earths consists of the co-extraction of cerlum and rare earths. The aqueous feed Is adjusted to contain HEDTA or other suitable complexing agents to prevent extraction of lons such as lead and iron into the organic solvent $(0.4 M$ DEDHPA, 0.2M TBP, NPH).

To provide aged promethium, a crude feed was obtained from stored alkaline Purex vagte. This tank slurry was centrifuged in the Purex Plant. The solids were dissolved and the rare earths reprecipitated with oxallc acid. The oxalate preclpitate was dissolved and served as the crude rare earth feed for subsequent processing. The analysis of thls crude feed is shown in Table I.

\section{TABIE I}

\section{CRUDE RARE EARTH FHED}

$$
\begin{array}{ll}
\mathrm{Mn}^{++} & 15 \mathrm{~g} / \mathrm{l} \\
\mathrm{Fe}^{++} & 7.9 \\
\mathrm{Fo}^{++} & 10.3 \\
\mathrm{Al}^{++} & 0.6 \\
\mathrm{R} \cdot \mathrm{E} & 5.7 \\
\mathrm{Ce}^{++} & 0.4 \\
\mathrm{H}^{+} & 5.7
\end{array}
$$


From these results, it was realized that manganese would also require separation from the rave earths to prevent interference in the persulfat? step. Although manganese concentrations up to $1.2 \mathrm{~g} / 1$ were tested through the persulfate step without affecing $\mathrm{Ce}(\mathrm{IV})$ distribution ratios, $\mathrm{MnO}_{2}$ is precipitated out of solution and makes phase separation difficult. Manganese concentrations up to $0.25 \mathrm{~g} / 1$ can be tolerated.

Destruction of $\mathrm{S}_{2} \mathrm{O}_{3}=$ by reaction with $\mathrm{Mn}^{++}$is not the severe problem it may seem since part of the $\mathrm{Mn}^{++}$is converted to $\mathrm{MnO}_{4}^{-}$which is also an effective cerlum oxidant. Difficulties will be encountered only if the concentration of $\mathrm{Nm}^{++}$is high enough to result in $\mathrm{MnO}_{2}$ precipitation. 1) Separation of Manganese by Solvent Extraction

The plant has experienced difficulties in extracting the rare earths from the crude feed produced from the sludge leachings. Several initial laboratory experiments had indicated that it was possible to separate the rare earths from manganese without difficulty. A 5 gallon sample of the feed was therefore obtained for use in the High Ievel Radiochemical Facility. DIPA or HEDTA was added to portions of this feed, and cerlum distribution ratios were determined as a function of pH. Manganese distributions under similar conditions were obtained (Figure I).

These results verifled the feasibility of solvent exiraction for the separation of manganese from rare earths. Other experiments indicated that the equilibrium for the cerium distribution was reached within 60 seconds. A third set of data indicated that the feed, adjusted with either DMPA or MEDMA at a $\mathrm{pH}$ of $3.7-4.0$, was stable for at least 72 hours ( $>90$ per cent of the cerium remaining in solution). The plant 
BNWL- 187

$-6-$

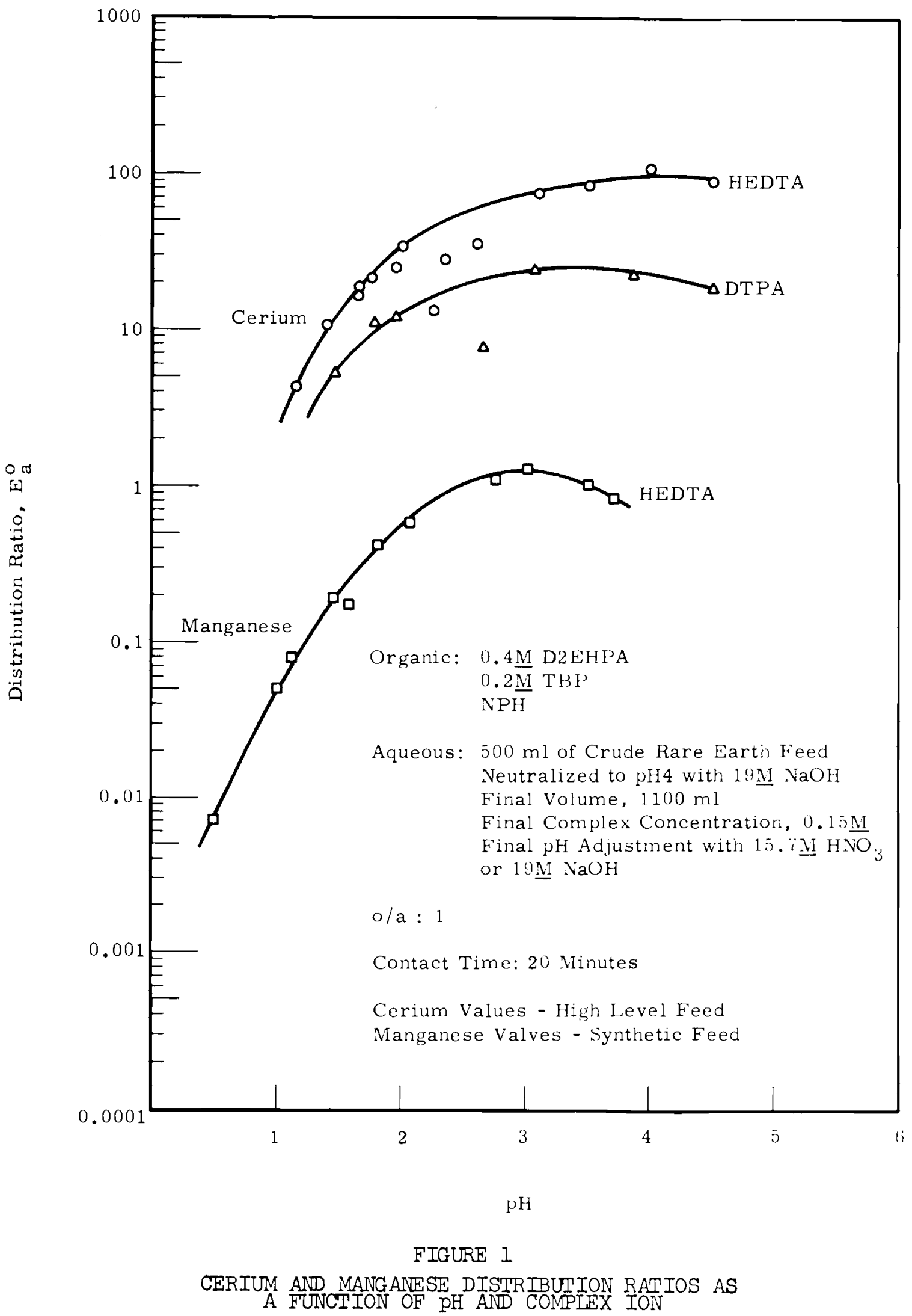


however, experienced a gross precipitation of cerium and presumably promethium after several days' delay in processing a feed made up with DTPA, adjusted to a pH of 2.5 to 4.0 . The precipitate was assumed to be a $(\mathrm{RE})_{2}\left(\mathrm{CO}_{3}\right)_{3}$ and had to be redissolved in $\mathrm{HNO}_{3}$ prior to further processing.

2) Separation of Manganese by Sulfate Precipitation

Because of the difficulty of $\mathrm{pH}$ control in the plant, the DaEHPA solvent extraction scheme for manganese removal proved impractical, and an alternate scheme was sought which could be performed in the limited plant equipment. A process, based on sulfate precipitation, was developed in the laboratory and then tested with actual feed in the High Level Radiochemical Facility. The application of a precipitation process was complicated by lack of a centrifuge in the plant, which necessitated use of multiple decantation for phase separation.

Rare earth sulfate precipitation methods are well known $(2,3)$. Usually the solution containing cerium and rare earths is adjusted to contain $\sim 1$ molar sulfate and the $\mathrm{pH}$ is adjusted to $\sim 0.5-1.0$. It was therefore surprising to observe a precipitation when sodium bisulfate $\left(\mathrm{NaHSO}_{4}\right)$ was added to a synthetic waste containing $\sim 6 \mathrm{M} \mathrm{H}^{+}$. As shown in Table II, complete cerium precipitation takes place when the final $\mathrm{SO}_{4}=$ concentration is $2.5 \mathrm{M}$. In this experiment the $\mathrm{H}^{+}$was $5.4 \mathrm{M}$. Under these conditions, manganese and iron remain in solution, thus providing an excellent separation from the rare earths without $\mathrm{pH}$ adjustment. The rare earth sulfate precipitate is then washed with IM $\mathrm{Na}_{2} \mathrm{SO}_{4}$ to remove traces of manganese and converted to a hydroxide precipitate by adding 3.5M NaOH. (The sulfate associated with the precipitate converts to $\mathrm{Na}_{2} \mathrm{SO}_{4}$ and is soluble.) No digestion period at an 
$-8-$

BNWL- 187

TABIE II

PRECIPITATION OF CERIUM - RARE EARTHS AS A FUNCTION OF SULFATE CONCENIRATION

\begin{tabular}{|c|c|c|c|}
\hline \multicolumn{3}{|l|}{ Conditions: } & \multirow[b]{2}{*}{$\begin{array}{c}\text { Final Precipitate } \\
\text { Volume } \\
\text { (MI) }\end{array}$} \\
\hline $\begin{array}{l}\text { Cerium in } \\
\text { Solution } \\
(\%) \\
\end{array}$ & $\begin{array}{c}\text { Manganese in } \\
\text { Solution } \\
(\%) \\
\end{array}$ & $\begin{array}{c}\text { Sulfate } \\
\text { Concentration } \\
(\mathrm{M}) \\
\end{array}$ & \\
\hline 23.6 & 90.9 & 0.8 & 3 \\
\hline 4.2 & 92.8 & 1.4 & 5.5 \\
\hline 1.6 & 93.8 & 1.9 & 5.5 \\
\hline 0.7 & 93.5 & 2.2 & 4.5 \\
\hline 0.3 & 100.0 & 2.5 & 3 \\
\hline
\end{tabular}


elevated temperature is required for metathesis. HEDTA is then added and the slurry adjusted to a $\mathrm{pH}$ of $2-3$ with $\mathrm{HNO}_{3}$. The slurry will completely dissolve at $\sim \mathrm{pH} 7$ and the rare earths will remain in solution as long as the complexant (HEDTA) is present to compete with the sulfate. After defining the sulfate procedure in the laboratory a series of tests, using actual feed, were completed in the High Level Radiochemtcal Facility. The first test, using an equal volume of $5 \mathrm{M} \mathrm{NaHSO}_{4}$ to feed, precipitated 99 per cent of the cerlum and carried 14 per cent of the manganese. $\mathrm{A} \mathrm{IM} \mathrm{Na}_{2} \mathrm{SO}_{4}$ wash was used in subsequent tests to reduce the manganese contamination.

A second sulfate precipitation was also performed as follows:

\section{Precipitation}

1) Take $400 \mathrm{ml}$ plant feed

2) Add $400 \mathrm{ml} 5 \underline{\mathrm{M}} \mathrm{NaHSO}_{4}$

3) Heat $80^{\circ} \mathrm{C} 30$ minutes

Wash

1) Wash precipitate, $800 \mathrm{ml} 1 \mathrm{M} \mathrm{Na} \mathrm{SO}_{4}$

Metathesis and Dissolution

1) Add $600 \mathrm{ml} 3.5 \mathrm{M} \mathrm{NaOH}$ to the precipitate

2) Add 0.15 moles HEDTA

3) Adjust $\mathrm{pH}$ to 2.9 with $15.7 \mathrm{M} \mathrm{HNO}_{3}$

Solvent Extraction

1) Contact adjusted aqueous feed with $0.4 \mathrm{M}$ D2EHPA, $0.2 \mathrm{M} T \mathrm{TBP}, 0 / \mathrm{a}=1$, final $\mathrm{pH} 2.6$ 


\section{Cerium - Rare Earth Partition}

1) Contact loaded organic with $2 \mathrm{M}_{-} \mathrm{HNO}_{3}$,

$0.2 \mathrm{M} \mathrm{Na}_{2} \mathrm{~S}_{2} \mathrm{O}_{8}, 0.02 \mathrm{M} \mathrm{AgNO}_{3}, 0 / \mathrm{a}=1$,

15 minutes.

Approximately 2 per cent of the cerlum was lost in both the precipitation and washing steps with an over-all recovery of 95 per cent prior to solvent extraction. Twenty per cent of the manganese was associated with the initial sulfate precipitate, but after the sulfate wash step only 0.7 per cent remained to give a manganese decontamination factor of 140 .

The extraction step gave a cerlum distribution of $>100$. The ceriumrare earth partition gave a cerfum decontamination factor greater than 100 . Subsequent plant processing of the crude cerium-rare earth feed, using the sulfate precipitate method, has verified the laboratory results.

\section{B. Partition of Cerium from Trivalent Rare Earths}

The extraction of $\mathrm{Ce}$ (III) and trivalent rare earths into solvents such as D2EHPA in the $\mathrm{pH}$ range of 1 to 4 is well known ${ }^{(4)}$. Trivalent rare earths and $\mathrm{Ce}$ (III) may then be removed from the organic phase by stripping with mineral acids (Figure 2). Ce(IV), however, extracts completely into D2EHPA with high extraction coefficients even in very acid solutions. This is the basis for a cerlum-rare earth separation step.

For many years analytical chemists have relied on oxidizing cerium to $\mathrm{Ce}$ (IV) for the separation of cerium from rare earths. The application of this well-known technique to the separation of radio-cerlum from the rare earths with solvents such as D2EHPA is hampered by the rapid destruction of the oxidizing agent in the extremely high radiation fields and the presence of easily oxidized materials carried over from prior process steps. Th1s 


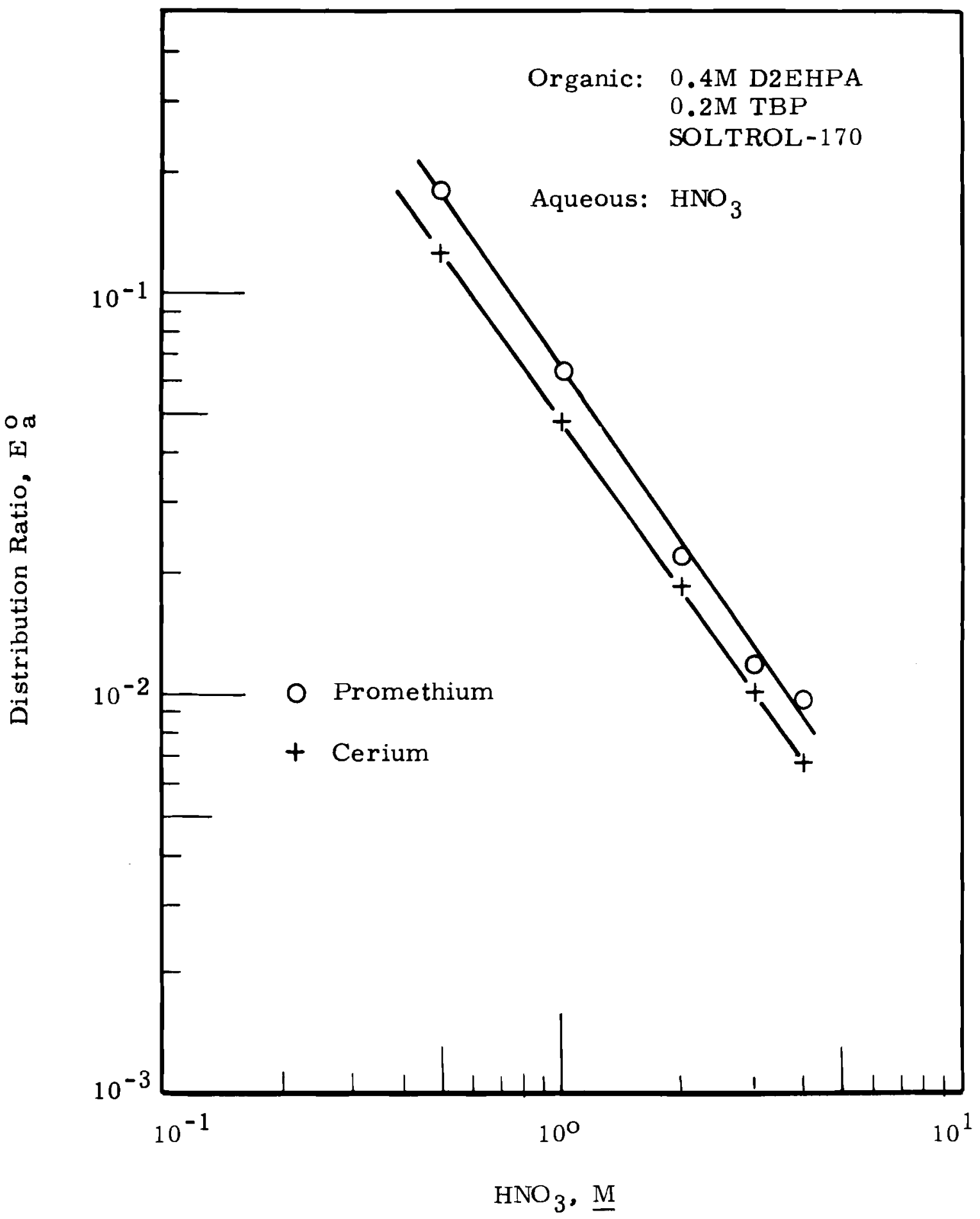

FIGURE 2 
destruction cannot be duplicated in cold laboratory experiments but is assumed to be caused in part by the degradation products formed by radiolysis of the organic solvent and in part by the direct radiolysis of the oxidant itself.

Workers at ORNL have studied the use of anodic oxidation (5) and potassium permanganate $^{(6)}$ as methods for forming cerium(IV). They found that it was necessary in the latter process to continuously add permanganate during the batch contact to maintain the tetravalent state. A serious disadvantage of this oxidant is that solid manganese dioxide is formed and results in very difficult phase separations. Another approach to the separation of cerium from trivalent rare earths is the precipitation of cerium peroxyacetate $(7,8)$. This process also falled to routinely produce a satisfactory separation because of difficulties with $\mathrm{pH}$ control and radiolysis of the peroxide. An oxidizing agent for use in extraction of fission product cerium must meet the following requirements:

- A sufficiently high potential to quantitatively oxidize cerium.

- Sufficiently slow kinetics so as not to react rapidly with the organic solvent.

- High radiation stability.

The persulfate ion has the se properties. Unfortunately its reaction rate with cerium is so slow that at room temperature oxidation does not occur. However, addition of silver ion markedly increases the rate of cerium oxidation. Silver ion acts as a catalyst for persulfate in the oxidation of cerium. The following rate controlling step has been proposed (9)

$$
\mathrm{S}_{2} \mathrm{O}_{8}=+\mathrm{Ag}^{+}=\mathrm{SO}_{4}=+. \mathrm{SO}_{4}{ }^{-}+\mathrm{Ag}^{++}
$$


BNWL -187

The sufate radical lor. $\mathrm{SO}_{4}^{-}$and the $\mathrm{Ag}^{++}$act as the active oxidants in this proposed mechanism. It was found in the intial investigation ( 1 ) that, the reaction rate could be covirolied by the concentration of silver and by the reaction temperatum. As shown in Figure 3, it is essential to keep the temperature low for batoh corsacts to allow the aerium(IV) to be held in the orgaric phase long enough to permit the separation of the phases. However, when considering a solvent extraction colum operation, in which resilence times are in the order of $1-5$ minutes, high reactior temperatures $\left(50-60^{\circ} \mathrm{C}\right)$ would be advartiageous.

1) Effect of Radiation on the Solvent - A series of experiments were performed in the High Lovel Radiochemical Facility to determine ths effect of radiation or cerlum extractions. These experiments were carried ouiv by contacting an aqueo:2s phase cottaining 300 curles/liter of $\mathrm{Ce}^{144}, 0.2 \mathrm{M}$ $\mathrm{K}_{2} \mathrm{~S}_{2} \mathrm{O}_{8}, 0.02 \mathrm{M} \mathrm{AgNO}_{3}$, and $2 \mathrm{M} \mathrm{HNO}_{3}$ with an equal volune of plant solvent (0.4M D2EYPA, 0.2M TBP in SOIIIROL-1:C) for up to 340 minutes. Samrles of bort phases were taken from time to time during the contact and the corium distribution measurea by the ir-c-11 gama spectrometer ${ }^{(1 C)}$. The aqueous phase was then d:scarded and the cerium was stripped irto $2 \mathrm{M} \mathrm{HNO}_{3}$ allowing 16 hours for the strip step. Sufficient $\mathrm{K}_{2} \mathrm{~S}_{2} \mathrm{O}_{8}$ and $\mathrm{AgNO}_{3}$ weze then adjea to the syst $\leqslant m$ to give concertirations of $0.2 \mathrm{M} \mathrm{K}_{2} \mathrm{~S}_{2} \mathrm{O}_{8}$ and $0.02 \mathrm{M} \mathrm{AgNO}_{3}$ in the aqueous phase and the cerfum ry-extracted as before. This sequen ae was repeates six times to simlate repated cycles of plant usage of the solvent. The SOITROI170 used in this experiment had been passed through a colum: of silica gel and then contacted with sulfuric acid prior to solvent make-up to insure the aksence of any unsaturated hydrocarbons.

Mrs mesults in Figine 4 are rot entirely corsistent but show a general decrease in the distribution ratio with re-use of the solverd. Also plotted 


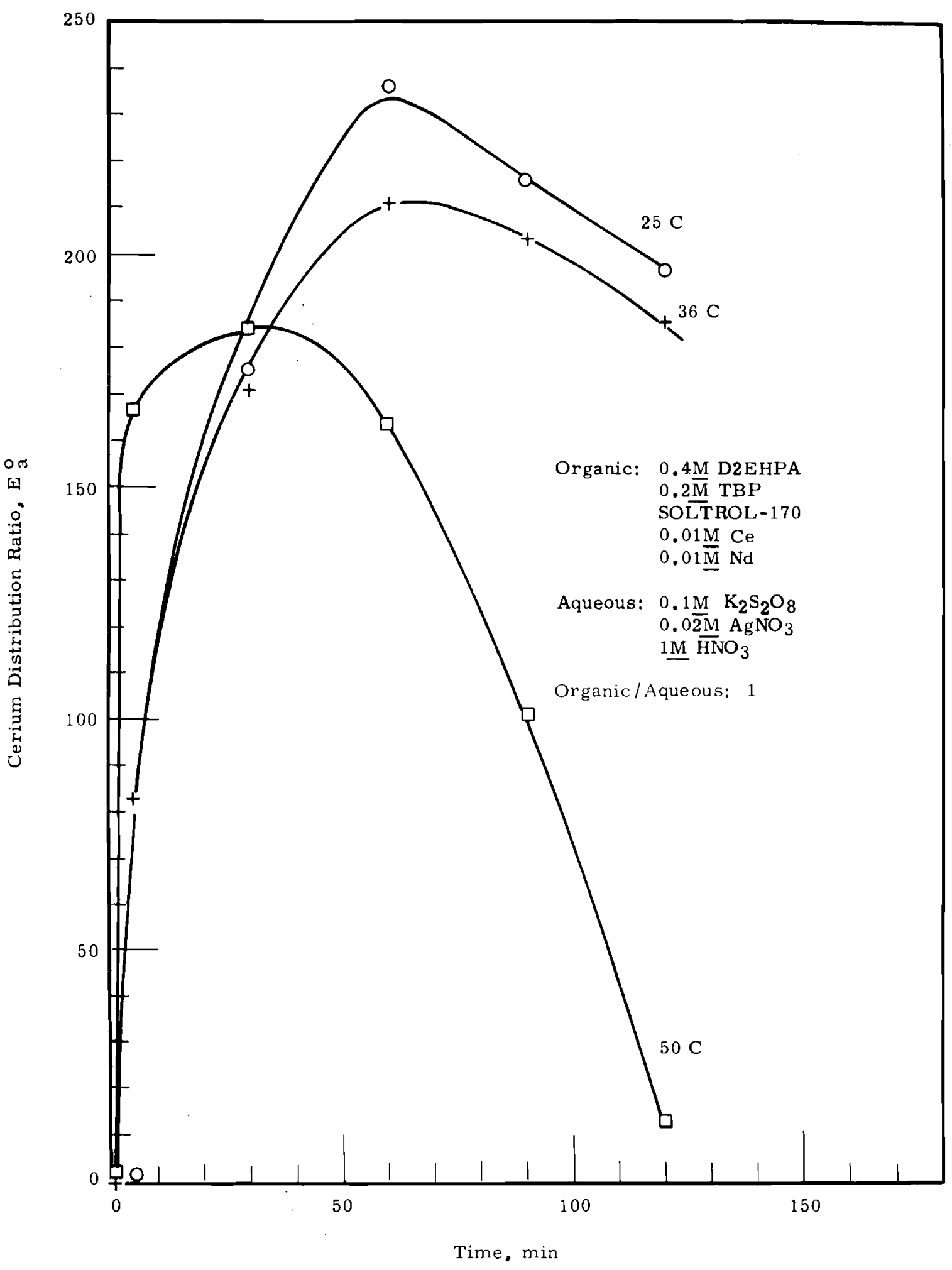

FIGURE 3 


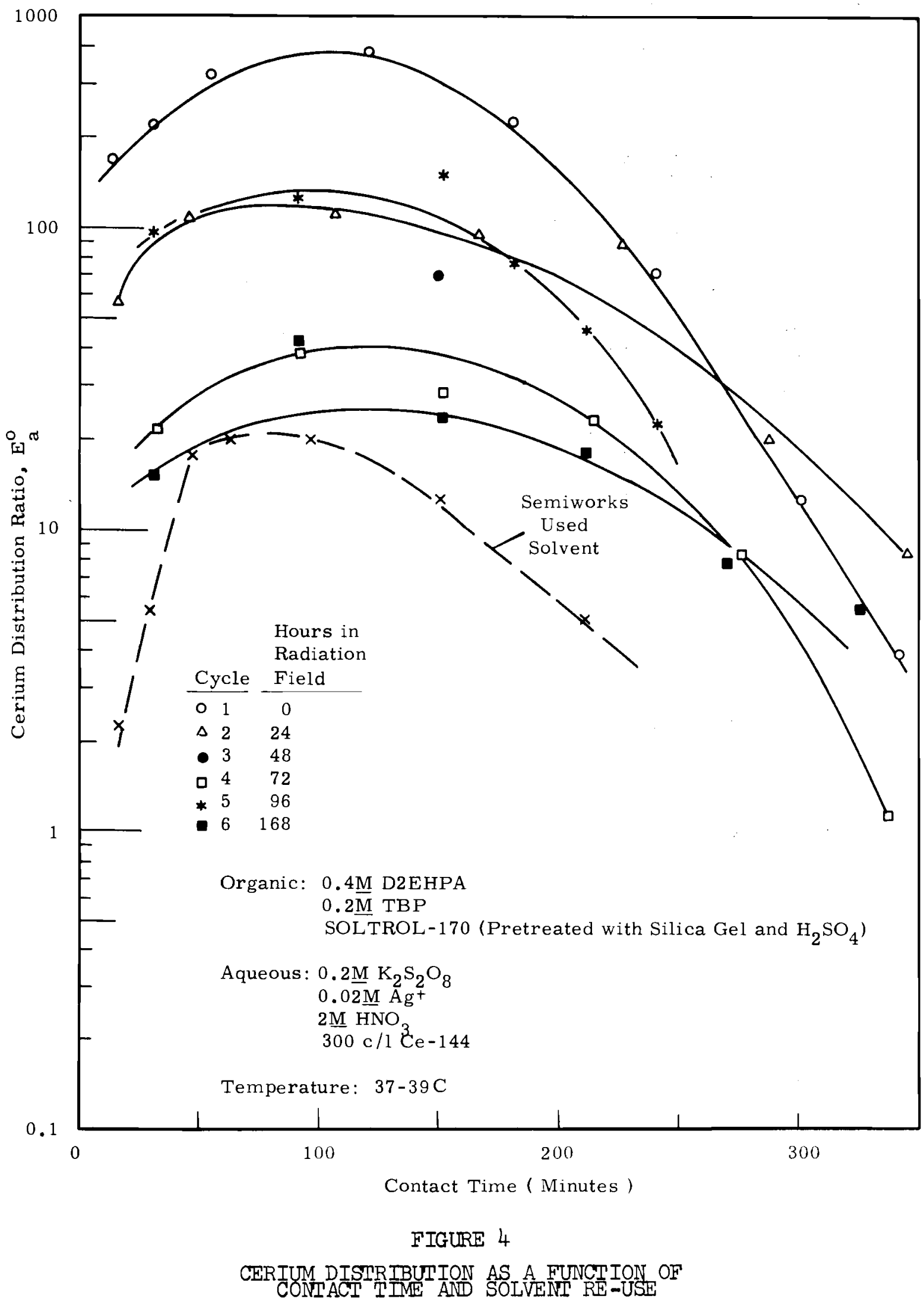


in this figure is a run similar to the above, but in which the solvent was "used" plant solvent. This solvent had been used for an undetermined number of strontium recovery runs and gave low distribution ratios for cerium, as was expected. Because of the pronounced decrease in cerium distribution with repeated use, it became imperative to find a more stable solvent.

E. C. Martin of this laboratory had investigated and recommended the use of a straight chain paraffin hydrocarbon in the Purex plant to reduce the fission product holdup in the organic solvent. Such a hydrocarbon is available in quantity at a reasonable cost from South Hampton Company, Houston, Texas. This diluent, referred to at Hanford as NPH (normal paraffin hydrocarbon), contains from 10 to 14 carbon atoms, and has been washed with sulfuric acid and silica gel treated prior to shipment.

Determination of cerium distribution ratios as a function of time of contact were performed using NPH as a diluent. Identical conditions were used as described above. Unfortunately sufficient cell time was not available to perform repeated cycles of extraction as before. However, to simulate these conditions the solvent was left in contact with the aqueous phase containing 300 curies/liter of cerium-144 for 150 hours and the distribution ratios measured again. The accumulated dose to the solvent would be roughly equivalent to that received by the SOLIROL-170 after six cycles. The data from these runs are plotted in Figure 5. Also show are the runs using SOLTROL-170 for the first and sixth cycle of use for comparison. These data indicated NPH to be a superior diluent to SOITROL-170, and its use has been adopted by the plant.

2) Effect of Pre-oxidation of Cerium - Several experiments were performed to determine if lower concentrations of potasaium persulfate and/or silver nitrate could be used if the cerlum were allowed to oxidize before 


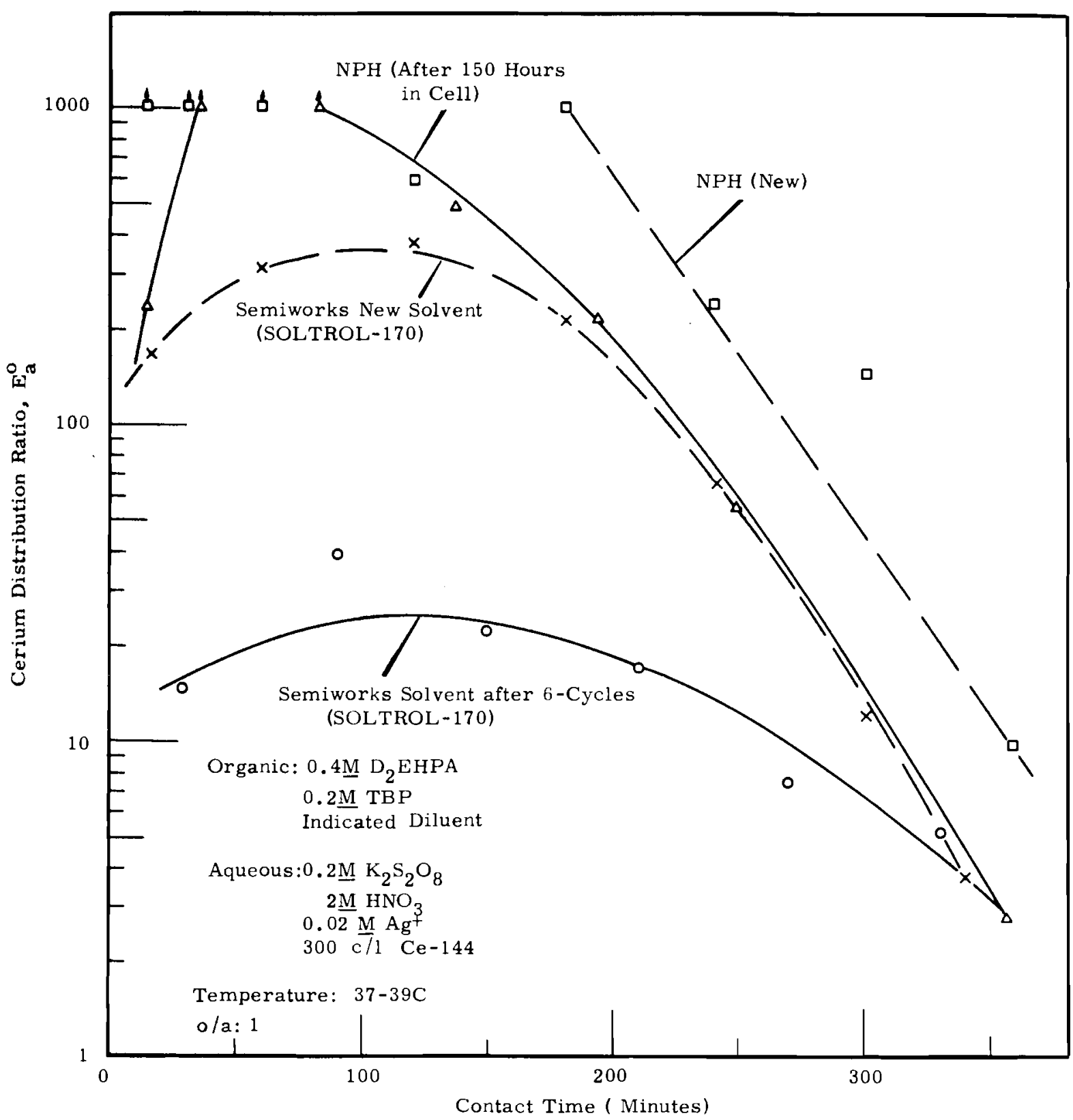

FIGURE 5

CERIUM DISTRIBUTION AS A FUNCTION OF CONRACT TIME (COMPARISON OF NPH AND SOITROL-170 AS DILUENSS) 
contacting the organic phase.

In these experiments, solutions containing 300 curies/liter of $\mathrm{Ce}^{144}$, $2 \mathrm{M} \mathrm{HNO}_{3}, 0.1$ or $0.05 \mathrm{M} \mathrm{K} \mathrm{K}_{2} \mathrm{O}_{8}$, and either 0.02 or $0.01 \mathrm{M} \mathrm{AgNO}_{3}$ were mixed for 45 minutes. The aqueous solution was then contacted with an equal volume of $0.4 \mathrm{M}$ D2EHPA, 0.2M TBP in SOIIROL-170 and sampled at intervals. The cerium distribution ratio was determined. The SOIITOL-170 was pretreated with silica gel and sulfuric acid as before. Used plant solvent was also tested.

The data obtained, as shown in Figure 6, indicate that very satisfactory cerium distribution ratios are obtained under these conditions with $0.1 \mathrm{M}$ potassium persulfate - 0.02M silver nitrate. Lower concentrations of either constituent produced unsatisfactory results for batch contact operations. The "used" solvent was completely unsatisfactory.

3) Solubility of Persulfate - The solubilities of both the potassium and sodium persulfate were measured and $\mathrm{Na}_{2} \mathrm{~S}_{2} \mathrm{O}_{8}$ found to be much more soluble. Solubility (at $25^{\circ} \mathrm{C}$ ) of $\mathrm{K}_{2} \mathrm{~S}_{2} \mathrm{O}_{8}$ in $0,1,2$ and $4 \mathrm{M} \mathrm{HNO}_{3}$ was $0.22,0.26,0.28$ and $0.37 \mathrm{M}$. The solubility of $\mathrm{Na}_{2} \mathrm{~S}_{2} \mathrm{O}_{8}$ was $2.4 \mathrm{M}$ in water and $1.7 \mathrm{M}$ in $2 \mathrm{M} \mathrm{HNO}_{3}$. Hot-cell performance of the two chemlcals was identical. Use of $\mathrm{Na}_{2} \mathrm{~S}_{2} \mathrm{O}_{8}$ was accordingly recomended. Besides much lower make-up volumes and improved operating flexibility, a savings in reagent cost was also realized $\left(\sim 12.5 \mathrm{k} / \mathrm{mole} \mathrm{Na}_{2} \mathrm{~S}_{2} \mathrm{O}_{8}\right.$ vs $23.2 \mathrm{k} /$ mole $\left.\mathrm{K}_{2} \mathrm{~S}_{2} \mathrm{O}_{8}\right)$.

4) Strippling the Ce(IV)-Loaded Solvent - After cerium(IV) is extracted into $0.4 \mathrm{M}$ D2EHPA - 0.2M TBP - NPH, it must be stripped out of the organic extractant within a limited time to prevent degradation of the solvent. A series of experiments was performed in the High Level Radiochemical Facility to determine the conditions required for effective stripping. Figure 7 shows that a contact time $>200$ minutes is required for stripping 95 per cent of 


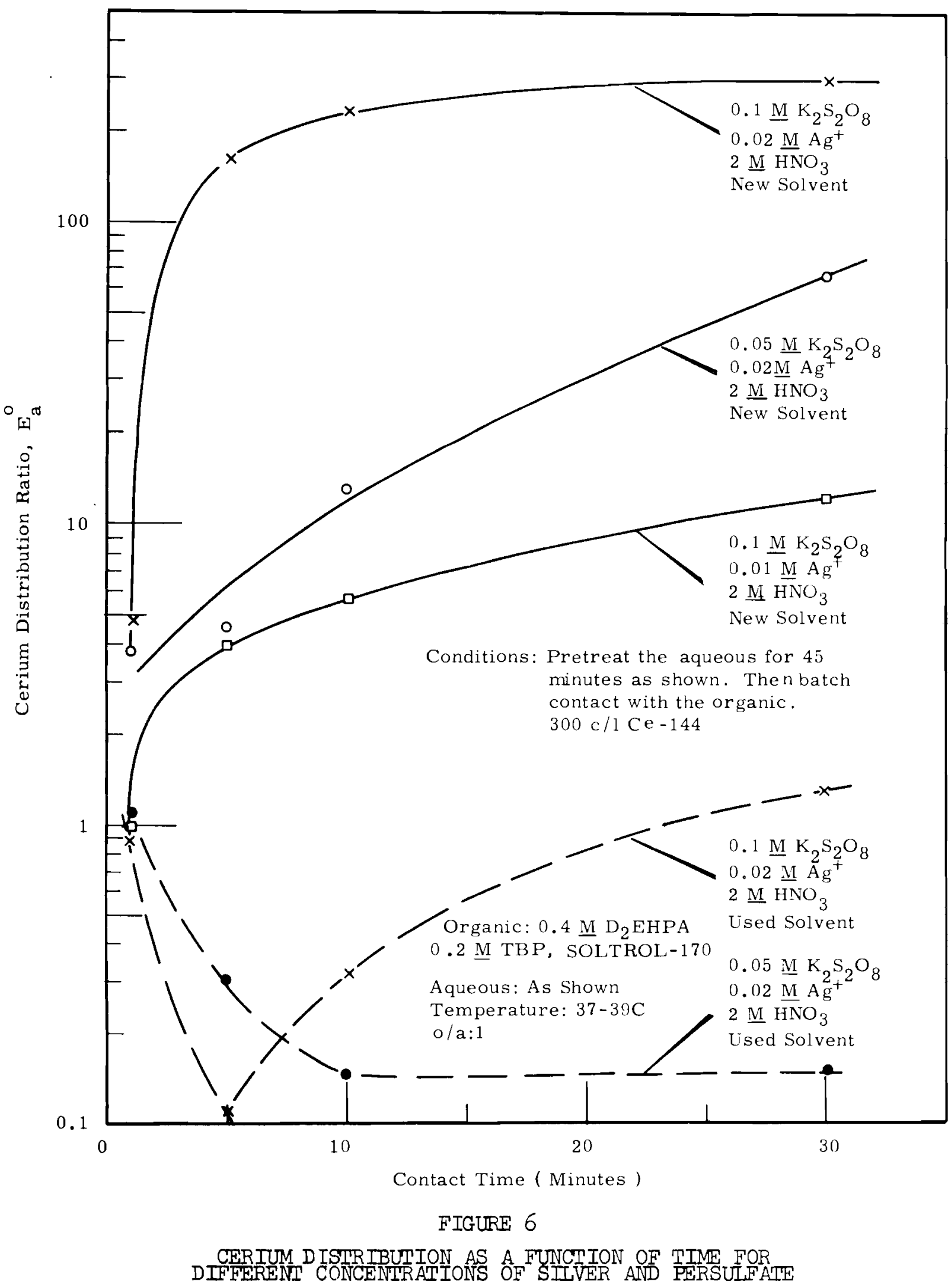




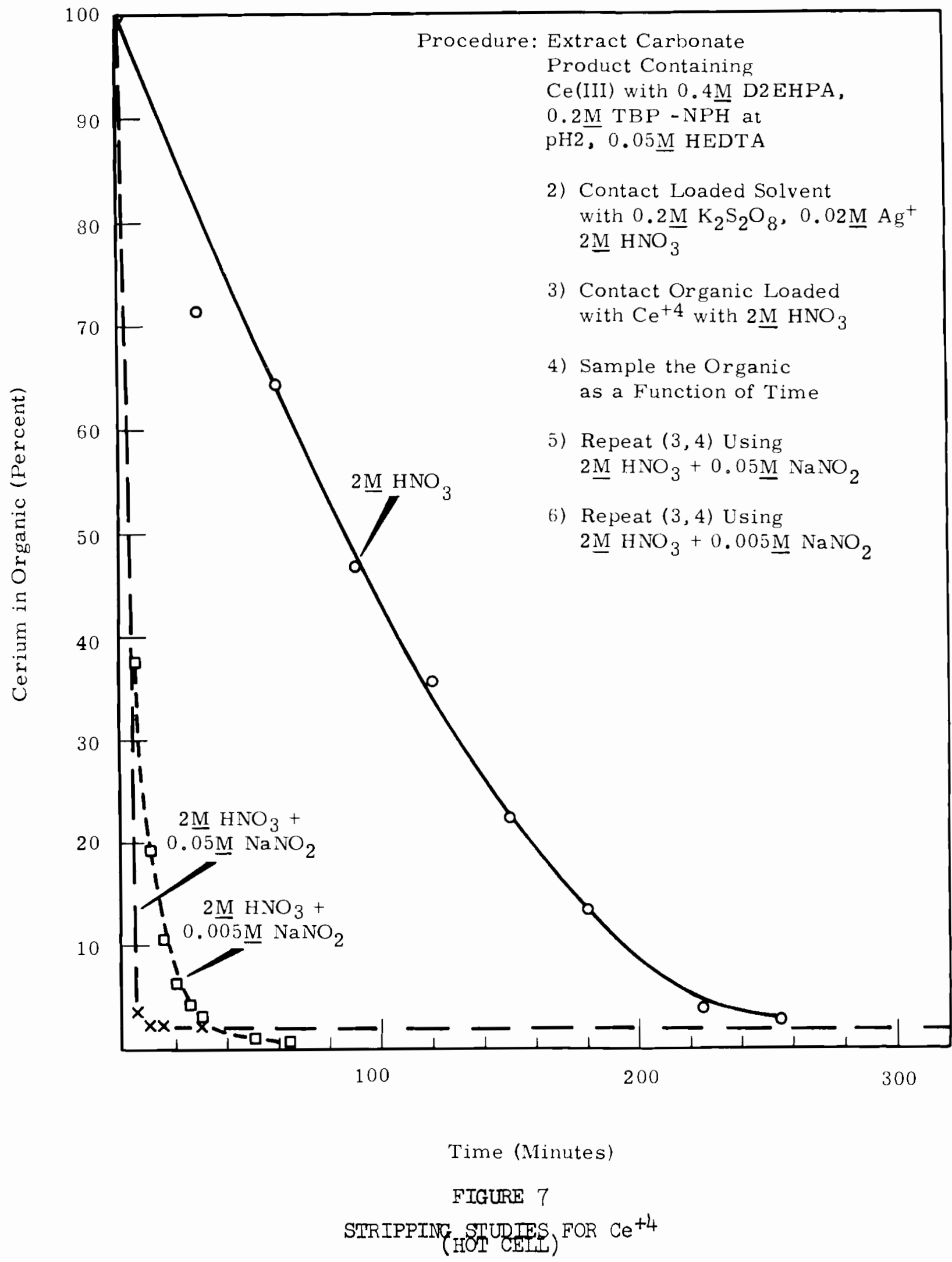


the cerium into $2 \mathrm{M}_{3} \mathrm{HNO}_{3}$. The addition of $0.005 \mathrm{M} \mathrm{NaNO}_{2}$ reduces the time to 25 minutes and $0.05 \mathrm{M} \mathrm{NaNO}_{2}$ to 5 minutes. Therefore, a $2 \mathrm{M} \mathrm{HNO}_{3}$ strip containing $0.005 \mathrm{M} \mathrm{NaNO}_{2}$ was recommended for batch contacts.

The cerium free extractant should then be washed with $2 \mathrm{M} \mathrm{HNO}_{3}, 0.2 \mathrm{M}$ $\mathrm{Na}_{2} \mathrm{~S}_{2} \mathrm{O}_{8}$ and $0.02 \mathrm{M} \mathrm{AgNO}_{3}$ to destroy entrained $\mathrm{NO}_{2}{ }^{-}$before being reused for cerium partition steps.

C. Re-Extraction of Trivalent Rare Earths

1) Trivalent Rare Earth Losses During the Sulfate-silver Removal Step

The undesired precipitation of rare earth double sulfates under conditions encountered in plant operation was also studied. A solution containing either $0.2 \mathrm{M}$ or $0.4 \underline{\mathrm{M}} \mathrm{K}_{2} \mathrm{~S}_{2} \mathrm{O}_{8}, 0.02 \mathrm{M} \mathrm{AgNO}_{3}, 0.001 \mathrm{M} \mathrm{Ce}\left(\mathrm{NO}_{3}\right)_{3}$, $0.01 \mathrm{M} \mathrm{Na}\left(\mathrm{NO}_{3}\right)_{3}$, trace amounts of $\mathrm{Ce}-144$ and $2 \mathrm{M} \mathrm{HNO}_{3}$ was heated 60 minutes at $80 \mathrm{C}$ to destroy the persulfate. Ce-144 was used to trace the path of the rare earths in these experiments because of the ease of its measurement. Hydrogen peroxide was added to insure that only $\mathrm{Ce}$ (III) was present and that all the persulfate was converted to sulfate. The $\mathrm{pH}$ was then adjusted to a desired value with $\mathrm{NaOH}$ and the solution was digested at 40-50 C for 60 minutes and centrifuged. The fraction of rare earths remainfing in the supernate was determined. The experiment was repeated with additions of citric acid or HEDTA prior to $\mathrm{pH}$ adjustment. The results (Figure 8) show rare earth losses by precipitation to be greater than 90 per cent at $\mathrm{pH} \geq 1$ in the absence of complexing agents. However at a pH $>2.8$ in the presence of $0.05 \mathrm{M}$ citric acid or HEDTA the rare earths remain in solution with $0.4 \mathrm{M}$ sulfate. Conditions were not found which would prevent rare earth precipitation when the solution contained $>0.4 \mathrm{M}$ sulfate. 


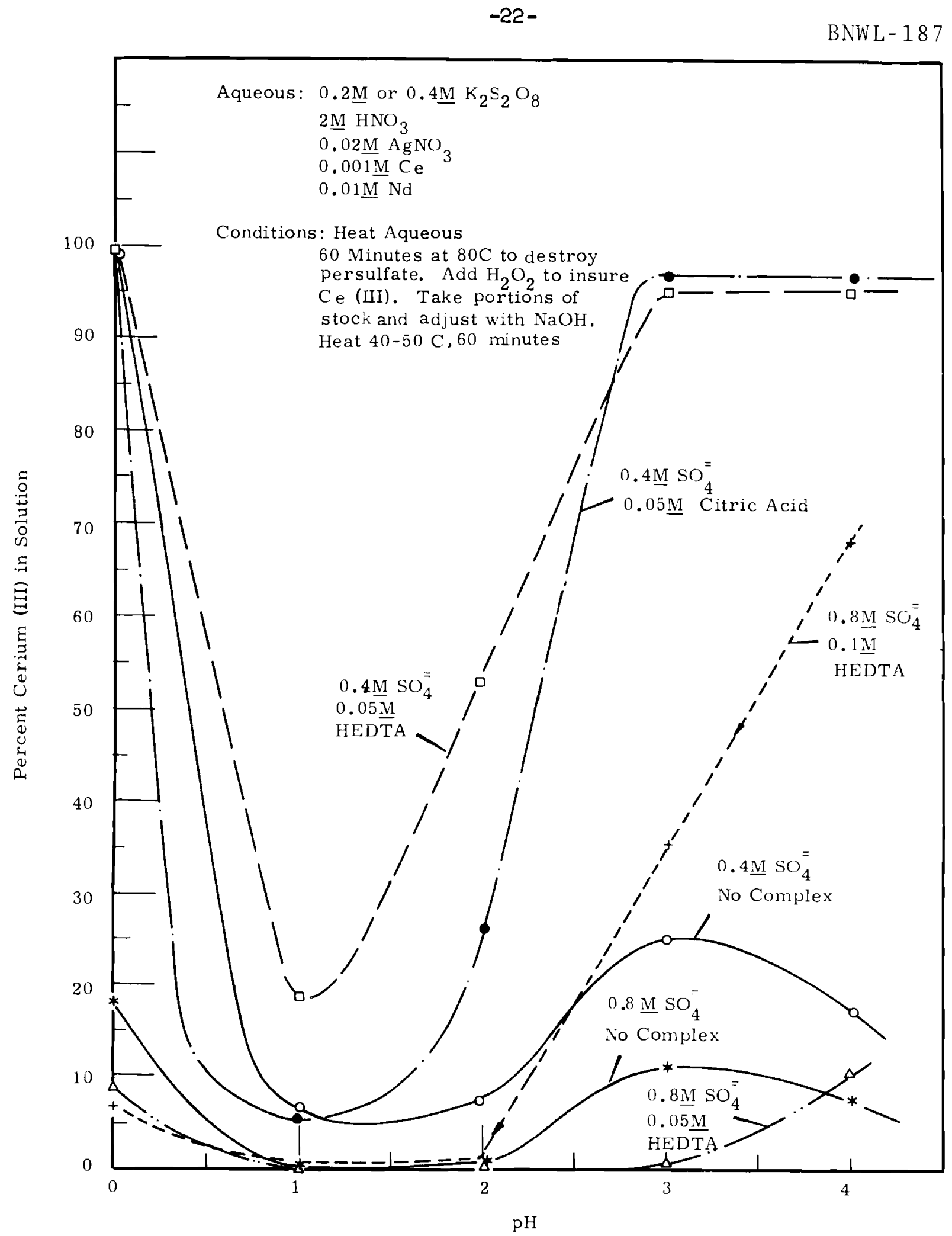

FIGURE 8

RARE EARTH SOLUBILITY IN THE PRESENCE OF VARYING CONCENIRATIONS OF SULFATE AND COMPLEXANT AS A FUNCTION OF PH 
BNWL - 187

To ascertain the solvent extraction behavior of rare earths complexed with HEDTA in the presence of sulfate, solutions prepared as described above were contacted with equal volumes of $0.4 \mathrm{M}$ D2EHPA, $0.2 \mathrm{M} T \mathrm{TBP}$, in NPH diluent and the cerium and promethium distribution ratios measured. HEDTA at $0.05 \mathrm{M}$ was chosen for the se experiments. The initial persulfate concentration was $0.2 \mathrm{M}$ in every case. The total rare earth concentration was varied from 0.01 to $0.03 \mathrm{M}$. The distribution ratios of silver were also measured. The results are shown in Figure 9. The data from Figures 8 and 9 indicate that a pH of 3 is nearly optimum. Part of the silver is also extracted but should not interfere in subsequent ion exchange separation of the individual rare earths.

2) Concentration and Dentiration of the Rare Earth Product

After the rare earths have been re-extracted into the organic, leaving the sulfate and sllver in the aqueous phase, they are stripped with $2 \mathrm{M}^{-} \mathrm{HNO}_{3}$. This solution is the feed for further purification by ion exchange. Because of the high acidity and large volume of this solution a concentration step is desired. Wheelwright has suggested a ratio of 0.2 mole of rare earths per mole of hydrogen ion as a desired feed condition for chromatographic purification of promethium(II). To meet this requirement, sucrose denitration $(12,13)$ was investigated.

A $1000 \mathrm{mr}$ solution containing $2 \mathrm{M}^{-} \mathrm{HNO}_{3}, 0.05 \mathrm{M} \mathrm{Na}\left(\mathrm{NO}_{3}\right)_{3}$ and $0.001 \mathrm{M}$ $\mathrm{Fe}\left(\mathrm{NO}_{3}\right)_{3}$ was concentrated and denitrated using sucrose to a final volume of $126 \mathrm{ml}$ and $2.2 \mathrm{M} \mathrm{H} \mathrm{H}^{+}$. The conditions were as follows:

1) Take $300 \mathrm{ml}$ of solution and concentrate to $100 \mathrm{ml}\left(6 \mathrm{M} \mathrm{HNO}_{3}\right)$.

2) Add $\sim 15 \mathrm{ml}$ of $2 \mathrm{M}$ sucrose to $700 \mathrm{ml}$ of the remaining solution. Slowly concentrate this by adding it to the $100 \mathrm{ml}$ in 1 ), keeping 


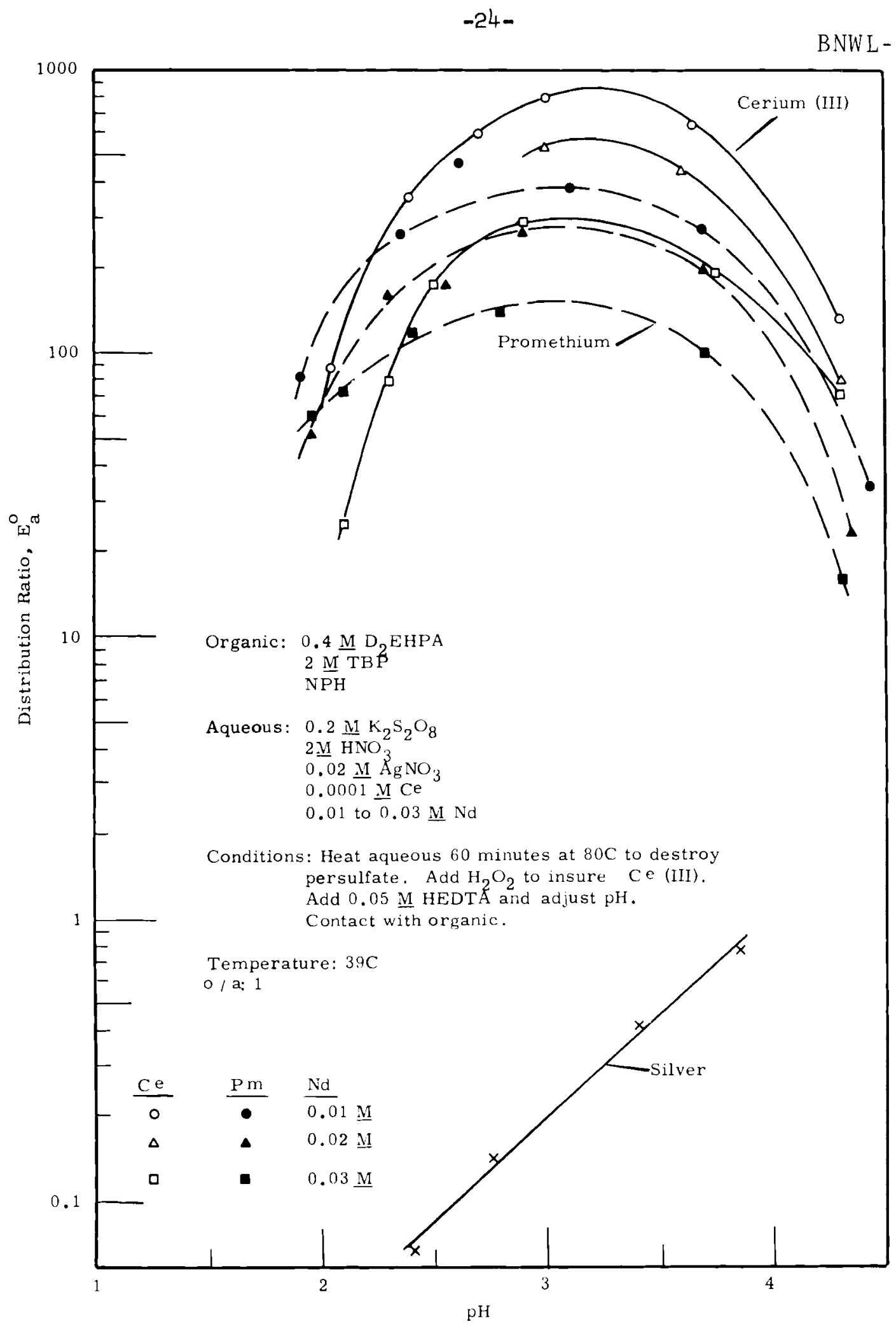

FIGURE 9

EXIRACTION OF RARE EARTHS AND SILVER FROM SULFATE SOLUTIONS CONRAINING HEDTA AS A FUNCTION OF pH 
the volume constant.

3) Digest the concentrated solution for 48 hours.

The volume was reduced by a factor of 8 . The residual carbon, $\mathrm{H}^{+}, \mathrm{NO}_{3}^{-}$and $\mathrm{Nd}$ final concentrations were $0.3 \underline{\mathrm{M}}, 2.2 \mathrm{M}, 3.2 \underline{\mathrm{M}}$ and $0.4 \underline{\mathrm{M}}$ respectively. The Na to $\mathrm{H}^{+}$ratio was 0.18 . This process was subsequently applied to an actual plant rare earth concentration-denitration with complete success.
\end{abstract}

\title{
IV. Future Rare Earth Processing
}

The development of a fission product cerium-rare earth separation process has been arduous. Early workers were only partially successful, mainly because of the intensive radiation fields encountered which destroyed the oxidizing agents or produced degradation products by radiolysis of the organic reagents. Varying rare earth feed sources containing high concentrations of iron, lead, manganese, sodium or other interferences have also added to the difficulties. Future source materials should be thoroughly analyzed for contaminants which might reduce the effectiveness of the oxldizing agent.

The current process consists of a batch sodium persulfate oxidation D2EHPA extraction to separate cerium(IV) from the trivalent rare earths. A straight chain paraffin inydrocarbon (NPH) is used as the diluent for the extractant. Even with these improvements, the difficult phase separation and long process time cyrles can result in high product losses and inefficient operation. A continuous process is essential for future rare earth processing. A solvent extraction colum proness has been proposed. "Cold" pilot plant studies have been completed by G. L. Pichardson (14), of this laborator ${ }^{\prime}$, to test the feasibility of such a process. The prelininary results are very favorable with cerium de contamination factors of $>135$. Most of the runs 
have been made with the feed heated to $60 \mathrm{C}$; with the aqueous phase continuous; with a strip solution containing $2 \mathrm{M}_{-} \mathrm{HNO}_{3}, 0.2 \mathrm{M} \mathrm{Na}_{2} \mathrm{~S}_{2} \mathrm{O}_{8}$, and $0.02 \mathrm{M} \mathrm{AgNO}_{3}$; and with a feed to organic flow ratio of $5 / 1$. The organic $\mathrm{Ce}(\mathrm{IV})$-loaded solvent is then stripped with $0.005-0.05 \mathrm{M} \mathrm{NaNO}_{2}$ and $2 \mathrm{M}_{-} \mathrm{HNO}_{3}$ - A more detailed stuc $y$ has been proposed for future applications and this, combined with the technology gained from the investigations now completed, should form the basis for the optimum rare earth flow sheet.

V. ACKNOWLEIGEMENTS

We gratefully acknowledge the assistance of Mrs. L. P. Power, T. R. Myers, R. C. Britton and G. O. Hamer who performed many of the laboratory experiments. The cooperation of S. J. Beard and his associates of the General Electric Company made possible obtaining actual plant solutions. Special thanks go to Dr. Robert Lee Moore under whose direction this work was performed. 
VI. REFERENCES

1. L. A. Bray and F. P. Roberts, Separation of Trivalent Rare Earths from Cerium, HW-78987-Rev., October 1963.

2. E. J. Wheelwright and W. H. Swift, The Recovery of Fission Product Rare Earth Sulfates from Purex 1WW, HW-63051. April 27, 1961.

3. L. A. Bray and H. H. Van Tuyl, Laboratory Development of a CarrierPrecipitation Process for the Recovery of Strontium from Purex Wastes, HW-69534. May 9, 1961.

4. R. P. Wischow and D. E. Horner, Recovery of Strontium and Rare Earths from Purex Wastes by Solvent Extraction, ORNL-3204. Oak Ridge National Laboratory, January 29, 1962.

5. R. E. McHenry, Separation of Cerium-144 from Other Rare Earths by Electrolytic Oxidation and Differential Extraction, ORN-TM-657, February 1965.

6. T. A. Butler and E. E. Ketchen, "Solvent Extraction Separation of Cerium and Yttrium from other Rare Earth Fission Products," Industrial and Engineering Chemistry, 53, pp. 651-654. 1961.

7. E. J. Wheelwright and N. C. Howard. The Separation of Cerium from the Trivalent Rare Earths Using Hydrogen Peroxide and Sodium Acetate, HW62505. May 18, 1960.

8. L. F. Lust and H. H. Van Tuyl, Peroxyacetate Separation of Cerium(IV) from Trivalent Rare Earths in Purex Process Solutions, HW-73135. March 26, 1962.

9. S. Fronaeus and C. O. Ostman, "The Mechanism of the Silver(I) Catalyzed Reaction Between Cerium(III) and Ammonium Persulphate," ACTA Chem. Scandia, 10, pp. 32-326. 1956.

10. U. L. Upson and F. F. Roberts, "An In-Cell Gama Analyzer", Nucleonics 2l, pp. 86-88, 1962. 
VI. FEFEFEINES (Continued)

11. E. J. Wheelwright and F. P. Roberts. Development and Demonstration of an Ion-Exchange Process for Kilogram Scale Production of High Purity Promethium, HW-78651 KEV. October 1963.

12. L. A. Bray, Denitration of Purex Wastes with Sugar, HW-76973 REV., Arril, 1963.

13. Lane A. Bray and Earl C. Martin, Method of Treating Radioactive Waste, U. S. Patent No. 3,158,577, June 20, 1963.

1. M T. Wallinf, Chrmistry Department Monthly Peport - Marce InEiz, BNWC-8 3C, Aprit 15, 1965 (Secret). 


\section{ONSITE DISTRIBUTION}

Copy Number

$$
\begin{aligned}
& 1-50 \\
& 51 \\
& 52-56 \\
& 57-58
\end{aligned}
$$

60

\author{
Pacific Northwest Laboratory \\ L. A. Bray \\ G. M. Dalen \\ Technical Information Files \\ Technical Publications
}

Richland Operations Office

R. K. Sharp

Technical Information Library 